\title{
The effect of low let (linear energy transfer) ionizing radiation to catalase activity of wistar's submandibular gland
}

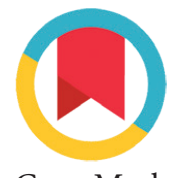

\author{
Nevy T. Putri, ${ }^{1 *}$ Sarianoferni, ${ }^{1}$ Endah Wahjuningsih ${ }^{2}$
}

\section{Abstract}

Objective: Intraoral periapical radiograph examination is the additional examination which is the most widely used in Dentistry. This radiograph examination using an $x$-ray ionizing radiation with low LET (Linear Energy Transfer) and may affect submandibular salivary gland. This study aimed to prove the effects of $x$-ray ionizing radiation with low LET towards the catalase activity of rattus norvegicus strain wistar's submandibular gland. Material and Methods: The subjects were 28 male wistar rats and divided into 4 groups ( $n=7$ ). Three groups were exposed 4, 8 and 14 times to radiation with $0.002 \mu \mathrm{Sv}$ for each exposure. The catalase activity of each rat was examined by a spectrophotometer. Data were analyzed using one-way ANOVA followed by Bonferroni test.
Results: The results showed the average of catalase activity on wistar rat's submandibular gland, respectively for: $0.150 \pm 0.0895$ (KK), $0.1405 \pm 0.0607$ (K1), $0.1228 \pm 0.0290$ (K2), $0.1227 \pm 0.0556$ (K3). Data showed significant differences of catalase activity between test groups, but showed not significant differences of catalase activity between each groups of rattusnorvegicus strain wistar's submandibular gland.

Conclusion: In this study concluded decreased catalase activity of rattusnorvegicus strain wistar's submandibular gland resulting from $x$-rays ionizing radiation by 4 times, 8 times and 14 times exposures.
${ }^{1}$ Department of Dental Radiography, Faculty of Dentistry, Hang Tuah University, Surabaya, Indonesia

${ }^{2}$ Department of Oral Biology, Faculty of Dentistry, Hang Tuah University, Surabaya, Indonesia

${ }^{*}$ Correspondence to:

Nevy Triditha Putri,

nevytriditha21@gmail.com

Received: 08 August 2016

Revised: 15 November 2016

Accepted: 22 November 2016

Available Online: 18 December 2016

Keywords: Catalase activity, submandibular gland, Wistar rat

Cite this Article: Putri NT, Sarianoferni, Wahjuningsih E. 2016. The effect of low LET (Linear Energy Transfer) ionizing radiation to catalase activity of wistar's submandibular gland. Journal of Dentomaxillofacial Science 1(3): 145-149.D0l:10.15562/jdmfs.v1i3.306

\section{Introduction}

Dental radiographic examination is one investigation that mostly used to establish the diagnosis, determine the treatment plan and evaluate the results of treatment. One of the dental radiographic examination used are periapical intraoral radiographic. Periapical intraoral radiographic essentially aimed to provide an overview of 2 to 4 tooth as well as the alveolar bone and surrounding tissue. ${ }^{1}$

Radiographic technique used to produce radiographs using $\mathrm{x}$-ray form of $\mathrm{x}$-ray beam from tube that fired the flow of high speed electrons on target positively charged to produce the image of the object to be examined., ${ }^{2,3} \mathrm{X}$-ray radiation is radiation with low Linear Energy Transfer (LET). ${ }^{4}$ LET is the magnitude of the energy that is move to the network by the distance of the travel. ${ }^{2}$

In addition of having great benefits, but also potentially the ionizing radiation pose a health risk to humans when it is uncontrolled. Although radiation is provided with a radiation dose and LET is low, patients can be repeatedly exposed by radiation. Alatas, ${ }^{4}$ said that from microdosimmetry effect, a low dose is below $1 \mathrm{mGy}$, but radiation at any low dose, may cause health effect due to ionization caused by exposure of radiation can cause
DNA damaged, so it is doubtful that there is no safe dose in terms of effect on human body.

The human body can not be fully protected from the risk of ionizing radiation during dental radiographic examination, especially on head and neck region. One of which is salivary glands. The function of salivary glands is to produce saliva which is play role in digestion, prevents dryness of the mucous, protect teeth from caries and to maintain homeostasis. Salivary glands consists of major salivary glands and minor salivary glands. One of the major salivary glands are submandibular salivary gland which is the second largest after the parotid glands that produce mucoid or serous. ${ }^{5}$

Exposure to ionizing radiation in the submandibular gland will cause the function become disrupted. This is supported by research of Sarioferni which proved that ionizing radiation photon and electron beams with high doses increasing the occurrence of apoptosis in the submandibular acini gland and cause a decrease in the saliva secretion. ${ }^{6}$

According to the human body which consists of $80 \%$ water, most of the interaction with ionizing radiation is indirectly. Indirect interaction that occurs is through the formation of free radicals caused by process of water molecule ionization. ${ }^{7}$ 
The human body itself has a defense mechanism against the free radical exposure, one of them by producing the catalase enzyme in the cells, where the catalase enzyme serves as a hydrogen peroxide dismutation catalisator into water and oxygen. ${ }^{8}$ Catalase enzyme produced by peroxisomes which located in the cytosol. Peroxisomes are small organelles which number in the hundreds in each cell. ${ }^{9}$

Based on the above, researchers want to determine the effect of ionizing radiation $\mathrm{x}$-rays which are the ionizing radiations with LET is low against the catalase enzyme activity in experimental animals submandibular gland rattus norvegicus and wistar strain. This research can not be performed in humans because it can damage the unit research experiment.

The experimental animals rattusnorvegicus wistar strain will be exposed in accordance with radiation dose on periapical intraoral radiographic examination is $0.002 \mu \mathrm{Sv}$ for a single exposure, given to patients at the Hospital Clinic of Dental Faculty of Dentistry, University of Hang Tuah Surabaya. The amount of exposure given is about 4 times and 8 times based on research that has been done before by Saputra ${ }^{10}$ to the effect of $\mathrm{x}$-ray radiation dental radiographic (conventional) to apoptosis and necrosis of the mucosal cells of the oral cavity, as well as 14 times exposure in accordance used in the manufacture of mounting radiograph, which is the value is equal to one dose exposure panoramic radiographs. Furthermore, the observation of the activity of catalase enzyme in the submandibular gland of the experimental animals.

\section{Material and Methods}

This research is true experimental type research, with research design post test only control group design. After going through ethics testing phase and examiner approved researchers conducted this study, researchers introduced wistar rats in accordance with the criteria of the sample. Subsequently, researchers performed acclimatization or adaptation on wistar rats for 7 days in rat cage to get a good general health and adapt with the environment. Cage placed in the room which is well ventilated and light by replacing the chaff 2-3 times a day. Food is given by placed in a small container and given 3 times a day at morning, noon and night. While drinks supplied in bottles of $300 \mathrm{ml}$, equipped with a small pipe filled with boiled water.

After acclimatization or adaptation for 7 days completed, researcher prepared to begin the treatment. Wistar rats were divided into 4 groups: control group without any treatment, group 1 treated with 4 times exposure to ionizing radiation $\mathrm{x}$-rays, group 2 with 8 times exposure ionizing radiation of $\mathrm{x}$-rays and group 3 with 14 times exposure ionizing radiation beam.

The tools used in this research is the rat cage, place for eat and drink, mice scales, dental intraoral radiography tool Kodak 2200 with a maximum voltage of $70 \mathrm{kVp}$ and current $7 \mathrm{~mA}$. The distance of cone and experimental animals is $20,5 \mathrm{~cm}$. Cone is directed to the mouth area of each Wistar rats, with fixation devices for mice was made of conical wire which is specifically created for this study, plywood, masks, handschoen, tool surgery rats to take the test material (scalpel, tweezers, surgical scissors, cotton), digital scales, test tubes, beaker, tubes for samples and test results, centrifuge with tube, micropipette, yellow and blue tip, a box contain of dry ice and spectrophotometer.

The materials used in this study is the food and beverage standards rattusnorvegicus wistar strain, ketamine-xylazine $0.1 \mathrm{ml}$ with a ratio of $1: 1$ for each rat, Phosphate Buffer Saline (PBS) $0.05 \mathrm{M}$ $\mathrm{pH} 7, \mathrm{H}_{2} \mathrm{O}_{2} 27.2 \mu \mathrm{M}, \mathrm{BSA}$ standard and supernatant submandibular salivary glands rattusnorvegicus wistar strain.

Exposure to ionizing radiation $\mathrm{x}$-rays at the head of a rat in the mouth area of each rat with the amount of exposure in accordance with the group that has been predetermined, the treatment groups were 4 times the exposure at a dose of $0.008 \mu \mathrm{Sv}$, treatment 8 times the exposure at a dose of 0.016 $\mu \mathrm{Sv}$ and 14 times exposure to a dose of $0.028 \mu \mathrm{Sv}$. Then the test material is done taking the submandibular glands of rats.

Before making the test material which is the submandibular glands of Wistar rats, first performed euthanasia on wistar rats by administering anesthesia to a mouse overdosed, injected intramuscularly in the thigh of mice with ketamine-xylazine material $0.1 \mathrm{ml}$ with a ratio of $1: 1$ for each rat.

After that perform the submandibular gland making procedures rattusnorvegicus wistar strain to then take measurements specific activity of the enzyme catalase, the calculation of the protein content, protein content and activity of catalase enzyme samples using a pectrophotometer with a wavelength $(\lambda) 210 \mathrm{~nm}$.

Data obtained from the research results were tabulated and analyzed descriptively that aims to obtain a picture of the distribution and summarizing data to clarify the presentation of the results, then test hypotheses using analytic statistical significance level of $95 \%(\mathrm{p}=0.05)$ using SPSS version 20. Hypothesis testing using parametric statistical tests. Normality test using the ShapiroWilk test and Levene statistic homogenesitas use. Then the data were analyzed using one-way 
ANOVA followed by post-hoc Bonferroni with a significance level of $\mathrm{p}<0.05$.

\section{Results}

Before the hypothesis test, each group was tested the normality using the Shapiro-Wilk test. Shapiro-Wilk test results showed that the normally distributed data and Levene test statistic to test the significant value of 0.187 homogenesitas obtained so that it can be concluded that the research data homogeneous $(\mathrm{p}>0.05)$ table 1 .

One Way ANOVA test results showed significant differences in the activity of the enzyme catalase submandibular gland rattusnorvegicus wistar strain. Furthermore, the Bonferroni test is used to determine the most significant differences between the treatment groups. Bonferroni test results show that there is no difference in the activity of the enzyme catalase meaningful or significant intergroup in the submandibular gland rattusnorvegicus wistar strain because of $\mathrm{p}>0.05$ figure 1 .

\section{Discussion}

Ionizing radiation is used in this research that $\mathrm{x}$-ray radiation that has a short wavelength and a radiation with LET is low. Exposure to radiation

\section{Catalase Activity}

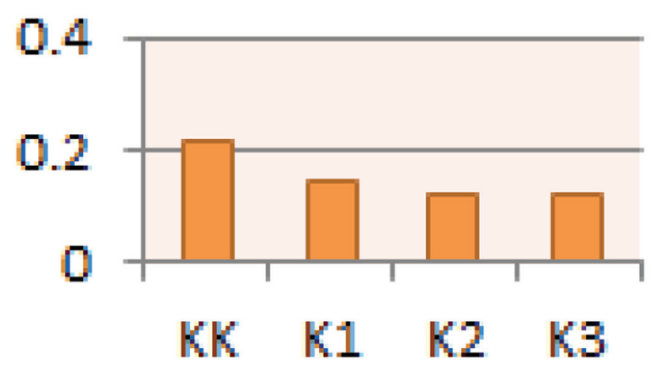

Figure 1 Mean chart from catalase activity of rattus norvegicus of wistar strain's submandibular gland

Table 1 Mean and standard deviations from catalase activity of rattus norvegicus strain of wistar's submandibular gland

\begin{tabular}{lc}
\hline Groups & Mean \pm standard deviations \\
\hline KK & $0.2150 \pm 0.0395$ \\
K1 & $0.1405 \pm 0.0507$ \\
K2 & $0.122 S \pm 0.0290$ \\
fG & $0.1227 \pm 0.0: 56$ \\
\hline
\end{tabular}

can cause damage to the body both at the level of molecular, cellular and tissue or organ. In the range of low doses of radiation can induce a series of changes at the molecular and cellular level that does not cause cell death but cause changes in the genetic material of cells to form new cells that are abnormal. The lower the dose received, the longer the time required for the onset of an effect, so that less information can be obtained. ${ }^{11,12}$

Ionizing radiation can cause tissue damage directly and indirectly. Damage occurs indirectly in the early stages of interaction of radiation with biological material where there is a transfer of energy when the electrons on neutral atoms, causing further ionization and excitation. ${ }^{13}$ This creates a very reactive ionized molecules. Oxidation or reduction reactions that occur interfere with the function of enzymes and nucleic acids to damage cell function and reproduction. ${ }^{14}$

Ionization process that occurs can lead to the formation of free radicals. Deposition occurs uneven energy in the cell and through a series of biochemical processes include the formation of free radicals at the molecular level and the release of biological mediators on cellular and tissue level. ${ }^{15}$ The existence of free radicals $\mathrm{H}^{+}$and $\mathrm{OH}^{-}$which is highly reactive and unstable in the body can lead to cellular damage, tissue and genetic (mutation). Free radicals have a very short half-life, because once formed, these components will immediately react with other molecules. ${ }^{14,15}$

Based on radiobiology studies, shows that the effects of ionizing radiation on cells, especially namely the occurrence of modifications in DNA. Biochemical changes that most concern is the damage and DNA repair and antioxidant enzymes. One of antioxidant enzymes is catalase enzyme. Catalase is one component of body fluids which can be taken as an indicator of biochemical response to radiation. ${ }^{16}$

The enzyme catalase is an endogenous antioxidant that works directly with the capture and describe the free radicals inside the cell becomes less reactive substances. Catalase included in the class of enzymes that can catalyze substrate hidroperoksidase hydrogen peroxide $\left(\mathrm{H}_{2} \mathrm{O}_{2}\right)$ and organic peroxide so as to prevent the occurrence of lipid peroxidation in cell membranes and works as a binder of free radicals. ${ }^{17,18}$

Catalase enzyme produced in peroxisomes in nearly all aerobic cells. Catalase enzyme activity contained in peroxisomes, directly degrades hydrogen peroxide into water and oxygen $\left(\mathrm{O}_{2}+2 \mathrm{H}_{2} \mathrm{O} \rightarrow\right.$ $2 \mathrm{H}_{2} \mathrm{O}_{2}$ ). Besides having the activity of peroxidase, catalase enzyme capable of using one molecule of hydrogen peroxide as a substrate or electron donor and molecules of hydrogen peroxide as the oxidant or other electron acceptors. ${ }^{19,20}$ 
Based on the results of research conducted, showed a decrease in activity of catalase enzyme in the submandibular gland rattusnorvegicus wistar strain due to exposure to ionizing radiations with LET is low, when compared with the control group without treatment group radiation exposure.

In the control group without treatment of radiation exposure, the activity of catalase enzyme in the submandibular gland is at $0.2150 \mathrm{U} / \mathrm{mg}$. In the treatment group 4 times the exposure to ionizing radiation, the activity of catalase enzyme in the submandibular gland decreased amounted to $0.1405 \mathrm{U} / \mathrm{mg}$. Furthermore, continued to decline in the treatment group 8 times the exposure to ionizing radiation is equal to $0.1228 \mathrm{U} / \mathrm{mg}$. In the treatment group 14 times the exposure to ionizing radiation decreased the activity of catalase enzyme in the submandibular gland, but not much different from the treatment group 8 times the exposure which amounted to $0.1227 \mathrm{U} / \mathrm{mg}$.

Based on the test results of parametric One-Way ANOVA showed that there are differences in the activity of catalase enzyme in the submandibular gland rattusnorvegicus wistar strain meaningful or significant to the results of significance of $0.032(\mathrm{p}<0.05)$, but based on advanced parametric Bonferroni test results indicate that there is no difference catalase enzyme activity that is meaningful or significant inter-group in the submandibular gland rattus norvegicus wistar strain because of $p>0.05$. Based on the research results obtained, proving that the indirect effects of ionizing radiation causes an increase in the number of free radicals results from molecular ionization process air. ${ }^{7} \mathrm{H}^{+}$and $\mathrm{OH}^{-}$formed is a strong oxidizing agent that is easily transformed into hydrogen peroxide $\left(\mathrm{H}_{2} \mathrm{O}_{2}\right)$.

The higher the formation of hydrogen peroxide $\left(\mathrm{H}_{2} \mathrm{O}_{2}\right)$, the enzyme catalase to catalysis more weight, which eventually suppress their activities. ${ }^{21}$ This condition causes the imbalance in the production of Reactive Oxygen Species (ROS) and endogenous antioxidant status called oxidative stress. The high oxidative stress is indicated by low cellular antioxidant status, so it is not able to eliminate the amount of oxidants or free radicals and result in damage to various molecules in cell or oxidative damage..$^{22}$

Changes in decreased activity of the enzyme catalase which is not much different between the treatment group 8 times the radiation exposure to the treatment group 14 times the radiation exposure is described in the research that has been done previously by conservation in 2011 on the activities of superoxide dismutase, catalase and levels malondialdehida gland submandibular wistar rats after irradiation gamma rays, citing studies using mice animal morphology may indicate infiltration of inflammatory cells in acinar cells irradiated gamma rays. The presence of inflammatory cells might explain the recovery of the cells after exposure to gamma rays, causing changes that are not much different between the treatment group 8 times the radiation exposure to the treatment group 14 times the radiation exposure in this study.

\section{Conclusion}

The results of this study concluded that exposure to ionizing radiations with LET it is low radiation $\mathrm{x}$-ray radiography intra-oral periapical 4 times, 8 times and 14 times the exposure decreases the activity of catalase enzyme in the gland submandibular rattus norvegicus strain wistar, and there are no differences in the activity of the enzyme catalase which significantly between groups in the submandibular gland rattusnorvegicus wistar strain.

\section{Conflict of Interest}

The authors report no conflict of interest.

\section{References}

1. Whaites E. Essentials of dental radiography and radiology. 4th ed. Elsevier; 2008. p. 29-31, 88, 91.

2. Edwards C, Statkiewicz MA, Ritenour ER. Perlindungan radiasi bagi pasien dan dokter gigi. Jakarta: Widya Medika; 1990. p. 88

3. Marpaung T. Peran PPR dalam radiologi diagnostik dan intervensional. Jakarta: Badan Pengawas Tenaga Nuklir; 2010.

4. Alatas Z. Efek kesehatan pajanan radiasi dosis rendah. Jakarta: Puslitbang Keselamatan Radiasi dan Biomedika Nuklir-BATAN; 2003.

5. Tamin S, Yassi D. Penyakit kelenjar saliva dan peran sialoendoskopi untuk diagnostik dan terapi. Jakarta: Departemen Ilmu Penyakit Telinga Hidung Tenggorok Fakultas Kedokteran Universitas Indonesia; 2012.

6. Sarianoferni. Apoptosis sel asinar kelenjar submandibularis tikus wistar jantan akibat radiasi ionisasi sinar photon dan elektron. Surabaya: Fakultas Kedokteran Gigi Universitas Airlangga Surabaya; 2009.

7. Supriyadi. Evaluasi apoptosis sel odontoblas akibat paparan radiasi ionisasi. Laboratorium Radiologi Kedokteran Gigi Fakultas Kedokteran Gigi Universitas Jember; 2008.

8. Hidayat YW, Pengaruh paparan radiasi telepon genggam terhadap aktivitas enzim katalase kelenjar parotis rattusnorvegicus strain wistar. Fakultas Kedokteran Gigi Universitas Hang Tuah Surabaya; 2014.

9. Yatim W. Biologi modern biologi sel. Bandung: Tarsito; 2003. p. 90.

10. Saputra D. Apoptosis dan nekrosis sel mukosa rongga mulut akibat radiasi sinar-x dental radiografik (konvensional). Fakultas Kedokteran Gigi UniversitasAirlangga Surabaya; 2012.

11. Alatas Z. Efek pewarisan akibat radiasi pengion. Jakarta: Pusat Teknologi Keselamatan dan Metrologi RadiasiBATAN; 2006.

12. Abbott P. Are dental radiographs safe?. Aust Dent J 2000.

13. Humaidi S. Dampak radiasi monitor komputer. Fakultas Matematika dan Ilmu Pengetahuan Alam Universitas Sumatera Utara; 2005. 
14. Syaifudin M. Indikator biokimia sel terhadap radiasi pengion. Jakarta: Puslitbang Keselamatan Radiasi dan Biomedika Nuklir-BATAN; 2005.

15. Rohmatussolihat. Antioksidan penyelamat sel-sel tubuh manusia. Staf Peneliti Pusat Penelitian Bioteknologi-LIPI; 2009.

16. Tukan MF. Kadar antioksi dan enzimatik katalase pada abortus inkomplit lebih rendah dibandingkan dengan kehamilan normal trimester pertama. Fakultas Kedokteran Universitas Udayana Denpasar; 2014

17. Pouget JP, Mather SJ. General aspects of the cellular response to low and high LET radiation. Europ J Nuclear Medicine 2001;28: 541-561.

18. Kohen R, Nyska A. Oxidation of biological system: oxidative stress phenomena, antioxidant, redox reaction and methods for their quantification. Toxic Pathol 2002;30: 620-650.

19. Zainuri M, Wanandi SI. Aktivitas spesifik manganese superoxide dismutase dan katalase pada hati tikus yang di induksi hipoksia sistemik: hubungannya dengan kerusakan oksidatif. Media LitbangKesehatan; 2012.

20. Winarsi H, Wijayanti SPM, Purwanto A. Aktivitas enzim superoksida dismutase, katalase, dan glutation peroksidase wanita penderita sindrom metabolik. Fakultas Biologi Universitas Soedirman Purwokerto 2012;44.

21. Urek MM, Bralic M, Tomac J, et al. Early and late effects of $\mathrm{x}$-irradiation on submandibular gland: a morphological study in mice. Arch Med Res 36: 339-343.

22. Hayati K. Aktivitas superoksida dismutase, katalase dan kadar malondial dehida kelenjar submandibularis tikus wistar setelah iradiasi sinar gamma. Fakultas Kedokteran Gigi Universitas Airlangga Surabaya 2011.

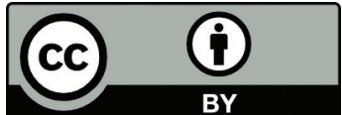

This work is licensed under a Creative Commons Attribution 